\title{
The Immune Microenvironment in Penile Cancer and Rationale for Immunotherapy
}

\author{
Mohamed E. Ahmed ${ }^{1, *,+} \mathbb{C}^{\mathbb{C}}$, Shayan Falasiri ${ }^{2,+} \mathbb{C}$, Ali Hajiran ${ }^{3}$, Jad Chahoud ${ }^{3}$ \\ and Philippe E. Spiess ${ }^{3}$ D \\ 1 Department of Urology, Mayo Clinic, Rochester, MN 55905, USA \\ 2 Department of Urology, University of South Florida Morsani College of Medicine, Tampa, FL 33612, USA; \\ falasiri@usf.edu \\ 3 Department of Genitourinary Oncology, H Lee Moffitt Cancer Center and Research Institute, \\ Tampa, FL 33612, USA; Ali.Hajiran@moffitt.org (A.H.); Jad.Chahoud@moffitt.org (J.C.); \\ Philippe.spiess@moffitt.org (P.E.S.) \\ * Correspondence: Mohamed.Ahmed@mayo.edu \\ + Indicates Co-first author.
}

Received: 21 September 2020; Accepted: 12 October 2020; Published: 17 October 2020

check for updates

\begin{abstract}
Penile cancer is an extremely rare malignancy that accounts for approximately $1 \%$ of cancer deaths in the United States every year. While primary penile cancer can be managed surgically, advanced and metastatic forms of the disease require more aggressive management plans with systemic chemotherapy and/or radiotherapy. Despite the meaningful response to systemic treatments, the 2-year progression-free survival and disease-specific survival have shown disappointing results. Therefore, there is a crucial need for alternative treatment options with more favorable outcomes and a lower toxicity profile. There are currently extensive studies of tumor molecular biology and clinical trials with targeted molecular therapies, such as PD-1, PD-L1, and CTLA-4. In this review, we will describe the penile cancer microenvironment, and summarize the rationale for immunotherapy in penile cancer patients.
\end{abstract}

Keywords: penile cancer; tumor microenvironment (TME); immune infiltration patterns; Programmed Death-1 Ligand (PD-L1); tumor mutational burden (TMB)

\section{Introduction}

Penile cancer (PeCa) is an exceedingly rare malignancy. In 2020, it is estimated that penile cancer will comprise $0.25 \%$ of male cancer incidence and account for 440 deaths in the United States [1]. Geographic disparities are pronounced between Western countries and the developing world, where incidence may run as high as 2.8-3.7 per 100000 [2]. Globally, penile cancer accounts for $34,475$ new cancer cases and 15,138 cancer deaths every year [3]. The vast majority ( $95 \%)$ of penile cancers is represented by squamous cell carcinoma (SCC) $[4,5]$. Known risk factors for penile SCC include phimosis, smoking, chronic inflammatory states, a high number of sexual partners, lack of circumcision, and human papillomavirus (HPV) infection [6-9]. While penile SCC has a separate entity of SCCs and treated differently, there are recent reports describing extensive similarities and commonalities in the genetic and pathogenesis regulators of SCCs of various sites, including both the general determinants in the cancer process, such as P53 and cyclin D1, or the specific regulators, such as NOTCH, SOX2, and TP63 genes [10].

Though penile SCC is an active area of research, therapeutic options are limited, with 5-year overall survival rates of $63 \%$ and $70 \%$ in the United States and Europe, respectively [11,12]. The extent of lymph node metastases at inguinal node dissection most strongly predicts prognosis as there are few 
effective therapies when the regional disease is present. Stratified by lymph node status, 5 -year overall survival is $>85 \%$ for patients with negative nodes and $29 \%-40 \%$ for patients with positive nodes [13]. Even for patients with clinically negative groins (cN0), the likelihood of metastasis approaches $25 \%$ [14]. Surgery remains the cornerstone of penile cancer treatment for both primary tumors and lymph node metastasis (LNM) with multimodal treatment, in the form of neoadjuvant chemotherapy or adjuvant radiation, reserved for advanced stages [15]. In regards to systemic therapy, while $50 \%$ of the patients achieve an objective response to taxane-ifosphamide-platinum regimens, the majority have demonstrated disappointing 2-year progression-free survival (PFS) and disease-specific survival (DSS) probability of $12 \%$ and $28 \%$, respectively [16-18]. Furthermore, Wang et al. reported poor survival outcomes of salvage treatment for disease recurrence after first-line chemotherapy, with a median overall survival of fewer than six months [19]. Thus, there is much interest in developing novel strategies with higher efficacy and low toxicity profile.

The discovery of Immune checkpoint inhibitors (PD1 / PD-L1 and CTLA-4) and the use of monoclonal antibody represent a revolutionary step in the management of many cancers. In an open-label phase 3 trial, treatment with pembrolizumab versus methotrexate, docetaxel, or cetuximab for recurrent or metastatic head-and-neck squamous cell carcinoma showed a favorable safety profile and prolonged overall survival [20]. The current advances in immunotherapy, along with the reported spectacular therapeutic outcomes, have inspired physicians to investigate the feasibility of its use in many cancers, including penile cancer. In this article, we review the microenvironment of penile carcinoma and provide a justification for immunotherapy use in these cases.

\section{Immune Infiltration Patterns (CD8, FOXP3 T regs)}

Tumor-infiltrating lymphocytes (TILs) have been frequently studied for their roles in triggering the host immune response to many forms of cancer, as well as in the processes of cancer immunoediting and immune escape [21]. Immunologically, tumors can be divided into three subgroups according to the number of intraepithelial and stromal cytotoxic T lymphocyte: (1) "Immune desert"; (2) "immune excluded"; and (3) inflamed [22-24]. The populations of lymphocytes compromising these infiltration patterns further stratify with ongoing investigations into $\mathrm{CD}^{+} / \mathrm{CD}^{+} \mathrm{T}$ cells, $\mathrm{CD}^{+} / \mathrm{CD}^{+} \mathrm{T}$ cells, and $\mathrm{CD}^{+} / \mathrm{CD}^{+} / \mathrm{FOXP}^{+} \mathrm{T}_{\text {reg }}$ cells (Figure 1) $[25,26]$. In pancreatic cancer, the ratio of $\mathrm{T}_{\text {regs }}$ to $\mathrm{CD} 4^{+} \mathrm{T}$ $\left(\% \mathrm{~T}_{\text {reg }}\right)$ has demonstrated a significant association with shorter survival, while tumor-infiltrating $\mathrm{CD} 4^{+}$ $\mathrm{T}^{\text {high }} / \mathrm{CD}^{+} \mathrm{T}^{\text {high }} / \% \mathrm{~T}_{\text {reg }}$ low independently predicted longer overall survival [26]. The IMvigor210 study provided evidence associating $\mathrm{CD} 8^{+}$density within the tumor with favorable atezolizumab response in metastatic urothelial cancer [27]. Thus, higher levels of $\mathrm{CD} 8^{+} \mathrm{T}$ cells is correlated with better prognosis in many cancers, including squamous cell carcinomas and urologic malignancies, however, there is growing evidence that sub-set populations of these $\mathrm{CD} 8^{+} \mathrm{T}$ cells are exhausted and lack their cytolytic activity, as well as the production of effector cytokines leading to impaired the antitumor activity $[28,29]$.

Specifically, in penile SCC, the immune infiltration patterns have generated considerable interest in further dissecting out this complexity. A recent study characterized the immune microenvironment in 54 patients with penile SCC using IHC with the immune markers: CD3, CD8, CD68, PD-1, PD-L1, Pancytokeratin, and DAPI. Notably, this cohort was analyzed for the effect of the exhausted, cytotoxic T cell population sub-type $\left(\mathrm{CD}^{+} / \mathrm{CD} 8^{+} / \mathrm{PD}-1^{+}\right)$, demonstrating that high densities of stromal cytotoxic, antigen-experienced $\mathrm{T}$ cells, suggestive of an immune excluded type, were significantly associated with worse median OS (27 vs. 102 months $p=0.05$ ) [30]. Another study by Ottenhof et al. in 2018 offered evidence that low stromal CD8 ${ }^{+} \mathrm{T}$ cell was associated with LNM [23]. In a 2015 study by Vassallo et al., penile SCC with high levels of tumor-infiltrating FOXP3 ${ }^{+} \mathrm{T}_{\text {reg }}$ cells bore a worse disease-free survival probability (HR 2.50, $p=0.02$ ) [31]. 

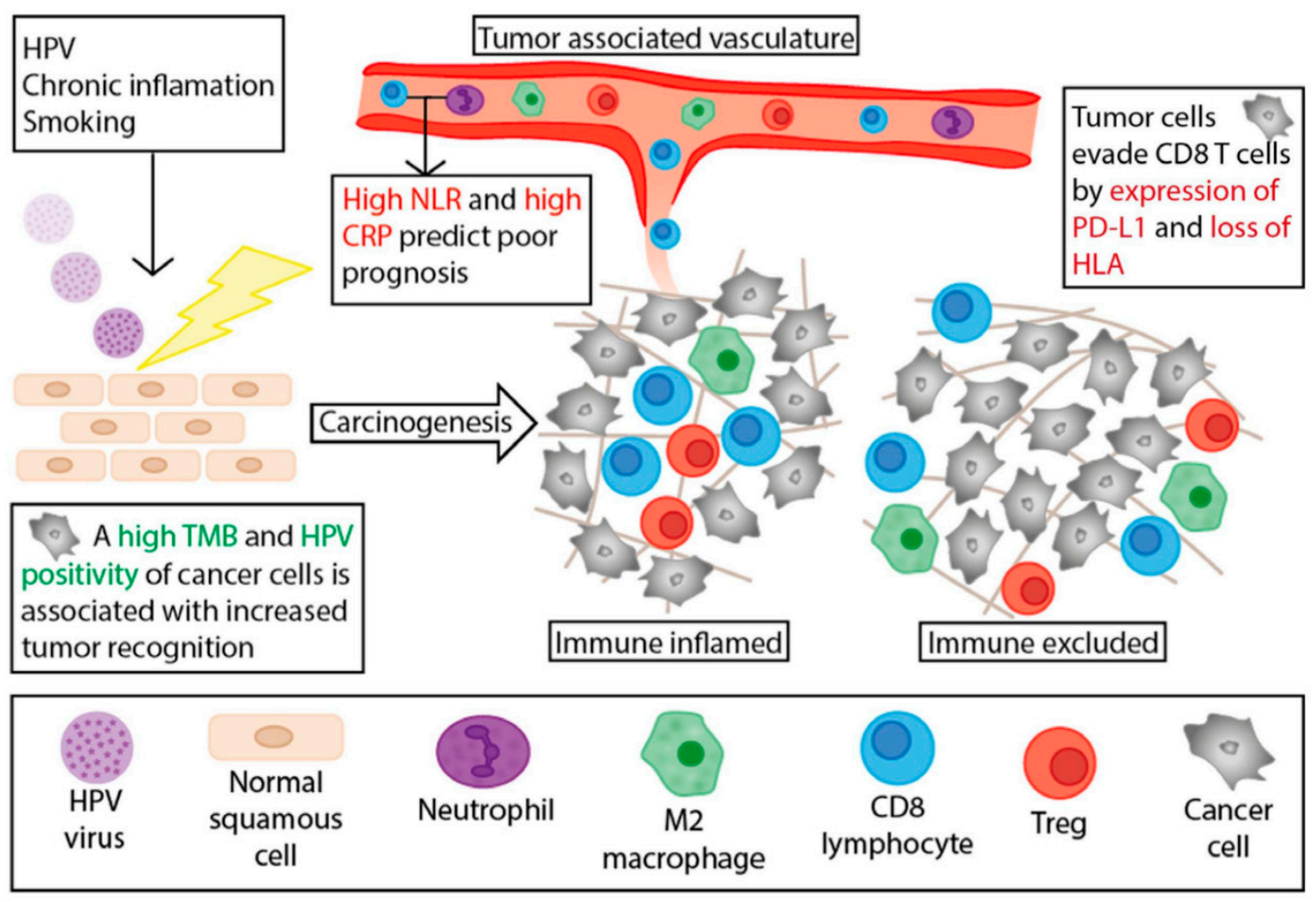

Figure 1. Illustrates tumor microenvironment in penile cancer (Reprinted with permission for Elsevier from "Defining the Tumor Microenvironment of Penile Cancer by Means of the Cancer Immunogram", by Hielke-Martijn de Vries et al., European Urology Focus, September 2019). Abbreviations: Treg = regulatory $\mathrm{T}$ cells, $\mathrm{HPV}=$ human papillomavirus; $\mathrm{TMB}=$ tumor mutational burden; NLR = neutrophil-to-lymphocyte ratio; $\mathrm{CRP}=\mathrm{C}$-reactive protein, $\mathrm{PD}-\mathrm{L} 1$ = programmed death-ligand 1 [25].

\section{PD-L1 Expression}

Programmed death-ligand 1 (PD-L1) has been detected in 40-60\% of penile SCC and mainly high-risk HPV negative tumors [32]. In many cancers, increased PD-L1 expression by either the tumor cells or the host immune cells, especially tumor-associated macrophages (TAMs), has correlated with poor prognosis and lower numbers of TILs [33]. Nearly two-thirds of primary penile SCC tumors are PD-L1-positive, with PD-L1 positivity defined by $>5 \%$ tumor expression [32]. In an immune histochemical study of 37 penile SCC, Udageret al. reported that PD-L1 expression in the primary tumor showed a significant association with regional lymph node metastasis (LNM, $p=0.024$ ), as well as shorter cancer-specific survival (CSS, $p=0.011$ ) [32] Additionally, In a multivariable analysis of 213 penile SCC patients, Ottenhof et al. reported that only diffuse PD-L1 expression in tumor cells was a significant predictor of lymph node metastases with OR of 2.81 ( $p$-value $=0.05)$. Furthermore, high-risk human papilloma virus-negative status (hrHPV) and diffuse PD-L1 expression in the tumor field demonstrated significant correlation with poor disease-specific survival with an HR of 9.73 ( $p$-value $<0.01)$, and HR of 2.81 ( $p$-value=0.03), respectively [23]. Moreover, in a recent case study, Trafalis et al. reported a partial response to nivolumab, an anti-PD-1 monoclonal antibody, in a patient with advanced hrHPV negative penile SCC refractory to chemoradiation therapies [34]. The authors reported a $>80 \%$ reduction in tumor volume after eight cycles of nivolumab. Of note, the patient pre-treatment histology showed $>5 \%$ expression of PD-L1, while post-treatment histology on residual tumor cells revealed attenuation of PD-L1 expression with significant augmentation of PD-L1 expression on immune cellular elements surrounding tumor cells, suggesting the use of combination therapy with an anti-PD-1/PD-L1 agent.

Ongoing penile SCC-related phase 2 clinical trials, targeting PD-L1/PD-1, include NCT02834013, NCT03333616, NCT03074513, and NCT02721732 [35-38]. NCT02834013 employs both nivolumab 
and ipilumumab in patients with rare tumors. NCT03333616 studying the combination of nivolumab and ipilumumab for advanced rare genitourinary tumors. NCT03333616 hopes to study how well atezolizumab and bevacizumab work in treating patients with rare solid tumors. NCT02721732 is evaluating the efficacy of pembolizumab in patients with rare tumors [38]. Table 1 summarized the most recent and ongoing clinical trials in penile cancer patients, as per 2020 updates. 
Table 1. Recent and ongoing immunotherapy clinical trials in penile cancers.

\begin{tabular}{|c|c|c|c|c|c|c|c|}
\hline \multirow{2}{*}{ Study Title } & \multirow{2}{*}{$\begin{array}{l}\text { Registration } \\
\text { Number }\end{array}$} & \multirow{2}{*}{ Trial Start Date } & \multirow{2}{*}{ Trial Status } & \multirow{2}{*}{ Agent } & \multirow{2}{*}{$\begin{array}{l}\text { Condition or } \\
\text { Disease }\end{array}$} & \multicolumn{2}{|c|}{ Study Outcomes } \\
\hline & & & & & & Primary Outcomes & Secondary Outcomes \\
\hline $\begin{array}{c}\text { Phase II Trial of } \\
\text { Pembrolizumab for } \\
\text { Advanced Penile Squamous } \\
\text { Cell Carcinoma Following } \\
\text { Previous Chemotherapy }\end{array}$ & NCT02837042 & October 2016 & Terminated & Pembrolizumab & $\begin{array}{l}\text { Advanced penile } \\
\text { squamous cell } \\
\text { carcinoma } \\
\text { following prior } \\
\text { chemotherapy }\end{array}$ & Objective response rate & $\begin{array}{l}\text { - Duration of response } \\
\text { - Progression-free } \\
\text { survival } \\
\text { - Overall survival } \\
\text { - Number of adverse } \\
\text { events } \\
\end{array}$ \\
\hline $\begin{array}{l}\text { A Phase 2, Multi-centre, } \\
\text { Open-label Study of } \\
\text { Avelumab (MSB0010718C) } \\
\text { in Locally Advanced or } \\
\text { Metastatic Penile Cancer } \\
\text { Patients Unfit for } \\
\text { Platinum-based } \\
\text { Chemotherapy or } \\
\text { Progressed on or after } \\
\text { Platinum-based } \\
\text { Chemotherapy }\end{array}$ & NCT03391479 & 15 August 2018 & Recruiting & Avelumab & $\begin{array}{l}\text { Locally advanced } \\
\text { or metastatic } \\
\text { penile cancer who } \\
\text { are unfit for or } \\
\text { progressed on } \\
\text { platinum-based } \\
\text { chemotherapy }\end{array}$ & Objective Response Rate & $\begin{array}{c}\text { - Progression-free } \\
\text { Survival Rate } \\
\text { - Overall Survival Rate }\end{array}$ \\
\hline $\begin{array}{c}\text { A Phase } 1 \text { Study of } \\
\text { Cabozantinib Plus } \\
\text { Nivolumab (CaboNivo) } \\
\text { Alone or in Combination } \\
\text { with Ipilimumab } \\
\text { (CaboNivoIpi) in Patients } \\
\text { with Advanced/Metastatic } \\
\text { Urothelial Carcinoma and } \\
\text { Other Genitourinary } \\
\text { Tumors }\end{array}$ & NCT02496208 & 9 July 2015 & Recruiting & $\begin{array}{l}\text { Cabozantinib } \\
\text { S-malate plus } \\
\text { Nivolumab, } \\
\text { plus/minus } \\
\text { Ipilimumab }\end{array}$ & $\begin{array}{l}\text { Advanced/Metastatic } \\
\text { Genitourinary } \\
\text { Tumors }\end{array}$ & $\begin{array}{l}\text { - Recommended dose } \\
\text { - Incidence of adverse } \\
\text { events }\end{array}$ & $\begin{array}{l}\text { - Clinical response rate } \\
\text { - Fraction of alive and } \\
\text { progression-free patients } \\
\text { at two months } \\
\text { - PDL-1 and MET } \\
\text { expression }\end{array}$ \\
\hline $\begin{array}{l}\text { A Phase II Study of } \\
\text { Nivolumab Combined with } \\
\text { Ipilimumab for Patients } \\
\text { with Advanced Rare } \\
\text { Genitourinary Tumors }\end{array}$ & NCT03333616 & $\begin{array}{l}28 \text { December } \\
2017\end{array}$ & Recruiting & $\begin{array}{l}\text { Ipilimumab plus } \\
\text { Nivolumab }\end{array}$ & $\begin{array}{l}\text { Advanced Rare } \\
\text { Genitourinary } \\
\text { Tumors }\end{array}$ & $\begin{array}{l}\text { - Objective Response } \\
\text { Rate }\end{array}$ & $\begin{array}{l}\text { - Duration of Response } \\
\text { - Immune-related } \\
\text { objective response rate } \\
\text { - Progression-Free } \\
\text { Survival } \\
\text { - Overall Survival } \\
\text { - Safety and tolerability }\end{array}$ \\
\hline
\end{tabular}


Table 1. Cont

\begin{tabular}{|c|c|c|c|c|c|c|c|}
\hline \multirow{2}{*}{ Study Title } & \multirow{2}{*}{$\begin{array}{l}\text { Registration } \\
\text { Number }\end{array}$} & \multirow{2}{*}{ Trial Start Date } & \multirow{2}{*}{ Trial Status } & \multirow{2}{*}{ Agent } & \multirow{2}{*}{$\begin{array}{l}\text { Condition or } \\
\text { Disease }\end{array}$} & \multicolumn{2}{|c|}{ Study Outcomes } \\
\hline & & & & & & Primary Outcomes & Secondary Outcomes \\
\hline $\begin{array}{l}\text { Phase II Study for the } \\
\text { Evaluation of Efficacy of } \\
\text { Pembrolizumab (MK-3475) } \\
\text { in Patients with Rare } \\
\text { Tumors }\end{array}$ & NCT02721732 & 15 August 2016 & Recruiting & Pembrolizumab & $\begin{array}{l}\text { Rare tumors, } \\
\text { including } \\
\text { metastatic and } \\
\text { stage } 4 \text { penile } \\
\quad \text { cancer }\end{array}$ & $\begin{array}{l}\text { - Non-progression rate } \\
\text { - Incidence of adverse } \\
\text { events }\end{array}$ & $\begin{array}{c}\text { - Objective response } \\
\text { (CR/PR) rates } \\
\text { - Duration of response } \\
\text { - Progression-free } \\
\text { survival } \\
\text { - Overall survival } \\
\text { - Safety and tolerability }\end{array}$ \\
\hline $\begin{array}{c}\text { DART: Dual Anti-CTLA-4 } \\
\text { and Anti-PD-1 Blockade in } \\
\text { Rare Tumors }\end{array}$ & NCT02834013 & 13 January 2017 & Recruiting & $\begin{array}{l}\text { Nivolumab plus } \\
\text { Ipilimumab }\end{array}$ & $\begin{array}{c}\text { Rare tumors, } \\
\text { including } \\
\text { squamous cell } \\
\text { carcinoma of the } \\
\text { penis } \\
\end{array}$ & $\begin{array}{c}\text { - Overall response rate } \\
\text { (ORR) }\end{array}$ & $\begin{array}{l}\text { - Safety and toxicities } \\
\text { - Clinical benefit rates } \\
\text { - Overall Survival (OS) } \\
\text { - Progression-Free } \\
\quad \text { Survival (PFS) } \\
\end{array}$ \\
\hline $\begin{array}{l}\text { PERICLES (Penile Cancer } \\
\text { Radio- and Immunotherapy } \\
\text { Clinical Exploration } \\
\text { Study)-a Phase } 2 \text { Study of } \\
\text { Atezolizumab With or } \\
\text { Without Radiotherapy in } \\
\text { Penile Cancer }\end{array}$ & NCT03686332 & $\begin{array}{l}25 \text { September } \\
2018\end{array}$ & Recruiting & $\begin{array}{l}\text { Atezolizumab } \\
\text { plus/minus } \\
\text { Radiotherapy }\end{array}$ & $\begin{array}{l}\text { Advanced penile } \\
\text { cancer }\end{array}$ & $\begin{array}{l}\text { - Progression-free } \\
\text { survival at } 1 \text { year }\end{array}$ & $\begin{array}{l}\text { - 2-year overall survival } \\
\text { rate of the complete } \\
\text { study population }\end{array}$ \\
\hline $\begin{array}{l}\text { The LATENT Trial: Lytic } \\
\text { Activation to Enhance } \\
\text { Neoantigen-directed } \\
\text { Therapy A Study to } \\
\text { Evaluate the Feasibility and } \\
\text { Efficacy of the Combined } \\
\text { Use of Avelumab with } \\
\text { Valproic Acid for the } \\
\text { Treatment of } \\
\text { Virus-associated Cancer }\end{array}$ & NCT03357757 & 7 February 2018 & Recruiting & $\begin{array}{l}\text { Avelumab plus } \\
\text { Valproic Acid } \\
\text { (VPA) }\end{array}$ & $\begin{array}{l}\text { Human papilloma } \\
\text { virus-associated } \\
\text { cancers }\end{array}$ & $\begin{array}{c}\text { - } 1 \text { year treatment } \\
\text { Efficacy } \\
\text { - Proportion of patients } \\
\text { who complete four doses } \\
\text { of Avelumab plus VPA }\end{array}$ & $\begin{array}{c}\text { - Overall survival } \\
\text { - Progression-free } \\
\text { survival } \\
\text { - Adverse events } \\
\text { - Identify virus-related } \\
\text { cancers for future studies }\end{array}$ \\
\hline $\begin{array}{l}\text { A Phase II, Single-Arm } \\
\text { Open-Label Study of the } \\
\text { Combination of } \\
\text { Atezolizumab and } \\
\text { Bevacizumab in Rare Solid } \\
\text { Tumors }\end{array}$ & NCT03074513 & 3 March 2017 & $\begin{array}{l}\text { Active, not } \\
\text { recruiting }\end{array}$ & $\begin{array}{c}\text { Atezolizumab, } \\
\text { plus Bevacizumab } \\
\text { (atezo bev) }\end{array}$ & $\begin{array}{l}\text { Rare solid tumors, } \\
\text { including penile } \\
\text { squamous cell } \\
\text { carcinoma }\end{array}$ & $\begin{array}{c}\text { - Objective response rate } \\
\text { (ORR) }\end{array}$ & $\begin{array}{c}\text { - ORR (iRECIST) } \\
\text { - Duration of response } \\
\text { (RECIST, iRECIST) } \\
\text { - PFS (RECIST, iRECIST) } \\
\text { - Overall survival }\end{array}$ \\
\hline
\end{tabular}


Table 1. Cont.

\begin{tabular}{|c|c|c|c|c|c|c|c|}
\hline \multirow{2}{*}{ Study Title } & \multirow{2}{*}{$\begin{array}{l}\text { Registration } \\
\text { Number }\end{array}$} & \multirow{2}{*}{ Trial Start Date } & \multirow{2}{*}{ Trial Status } & \multirow{2}{*}{ Agent } & \multirow{2}{*}{$\begin{array}{l}\text { Condition or } \\
\text { Disease }\end{array}$} & \multicolumn{2}{|c|}{ Study Outcomes } \\
\hline & & & & & & Primary Outcomes & Secondary Outcomes \\
\hline $\begin{array}{c}\text { A Phase 2, Open-Label } \\
\text { Study to Evaluate Efficacy } \\
\text { of Combination Treatment } \\
\text { with MEDI0457 (INO-3112) } \\
\text { and Durvalumab } \\
\text { (MEDI4736) in Patients with } \\
\text { Recurrent/Metastatic } \\
\text { Human Papilloma } \\
\text { Virus-Associated Cancers }\end{array}$ & NCT03439085 & $\begin{array}{c}14 \text { November } \\
2018\end{array}$ & Recruiting & $\begin{array}{l}\text { MEDI0457 } \\
\text { (INO-3112), plus } \\
\text { Durvalumab } \\
\text { (MEDI4736) }\end{array}$ & $\begin{array}{l}\text { Human papilloma } \\
\text { virus-associated } \\
\text { cancers }\end{array}$ & $\begin{array}{c}\text { - Overall Response Rate } \\
\text { (ORR); measured by } \\
\text { RECIST }\end{array}$ & $\begin{array}{l}\text { - ORR (iRECIST) } \\
\text { - PFS (RECIST) } \\
\text { - Disease control rate } \\
\text { - Overall survival } \\
\text { - Adverse events }\end{array}$ \\
\hline $\begin{array}{l}\text { Phase II Trial of M7824 in } \\
\text { Subjects with HPV } \\
\text { Associated Malignancies }\end{array}$ & NCT03427411 & 27 February 2018 & Recruiting & M7824 & $\begin{array}{l}\text { Human papilloma } \\
\text { virus-associated } \\
\text { cancers }\end{array}$ & $\begin{array}{l}\text { - Overall Response Rate } \\
\text { (ORR); measured by } \\
\text { RECIST }\end{array}$ & $\begin{array}{c}\text { - Duration of response } \\
\text { - PFS } \\
\text { - OS } \\
\text { - Safety and tolerability }\end{array}$ \\
\hline
\end{tabular}

Abbreviations: $\mathrm{CR}=$ complete response, $\mathrm{PR}=$ partial response, $\mathrm{ORR}=$ objective response rate, $\mathrm{PFS}=$ progression-free survival, $\mathrm{RECIST}=$ Response evaluation criteria in solid tumors, iRECIST = immune-based response evaluation criteria in solid tumors, OS = overall survival. 


\section{Macrophage/MDSC Infiltration Patterns}

Tumor-associated macrophages (TAMs) perform a major role in the tumor microenvironment by increasing angiogenesis, enhancing tumor cell mobility, and modulating immunotolerance. Both TAMs and TGF-B are found to be associated with VEGF, the expression of which has been demonstrated to be an independent prognostic factor for metastatic progression in penile carcinoma [39]. Moreover, TAMs have been implicated in establishing pre-metastatic niches, which may have a role as a tumor survival mechanism against systemic chemotherapy [35,40].

The continuously evolving paradigm divides TAMs into M1 (classical) macrophages

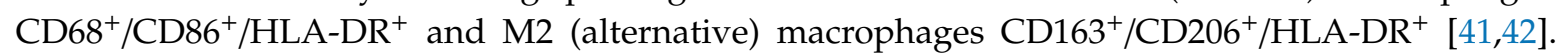
Studies in cancer patients have associated cancer progression and worse overall survival with the M2 phenotype [26]. In cervical SCC, M2-polarized TAMs have been identified to express PD-L1 [43]. In the context that PD-1 is found on most infiltrating CD8 + T cells and the evidence supporting PD-1/PD-L1 interactions as a driving factor behind cancer immune tolerance, these findings suggest that M2 TAMs may contribute to cancer immune escape [44]. In cervical SCC, M2 macrophage differentiation has been significantly linked to cancer-derived IL-6 and prostaglandin E2 [41]. Remarkably, M2 macrophages might be stimulated to classical tumor-rejecting M1 macrophages via CD40 interactions in the presence of IFN-gamma [41]. Additionally, IL6/JAK/STAT3 signaling pathway has been proposed as one of the mechanisms that can affect tumor microenvironment and immune response to tumor cells [45]. IL-6 activation induces JAK/STAT3 pathway in both tumor cells and tumor-infiltrating immune cells. Subsequently, myelomonocytic infiltrating tumor cells differentiate into impaired dendritic immune cells producing protumorigenic matrix-metalloproteinase (MMP-9) or M2 macrophages expressing PD-L1 that, in turn, suppresses cytotoxic T cell response $[45,46]$. Therefore, recent data suggests that IL-6/JAK/STAT3 signaling pathway may represent a therapeutic target to suppress tumor growth and activate the antitumor immune response [47,48]. However, in phase 2 clinical trials, the use of an anti-IL-6 monoclonal antibody in metastatic castration-resistant prostate cancer and in advanced solid tumors didn't show clinical benefits [49,50].

In penile SCC, high densities of $\mathrm{CD}^{+} 8^{+}$TAMs were associated with significantly improved cancer-specific survival (CSS) $(p=0.04)$, overall survival (OS) $(p=0.02)$, and lower risk of regional recurrence $(p=0.04)$ [30]. Another penile SCC group detected high intra-tumoral CD163 ${ }^{+}$corresponding with LNM [23].

In addition to that, Myeloid-derived suppressor cells (MDSC), believed to be immature bone marrow-derived hematopoietic progenitor cells failing, identified by $\mathrm{CD} 11 \mathrm{~b}^{+} / \mathrm{CD} 33^{+} / \mathrm{HLA}^{-\mathrm{DR}^{-}}$, and expressing several functional markers, such as arginase, represent a complex constituency of the TME with the ability to suppress T cell responses [51-53]. Monocytic MDSC (M-MDSC)

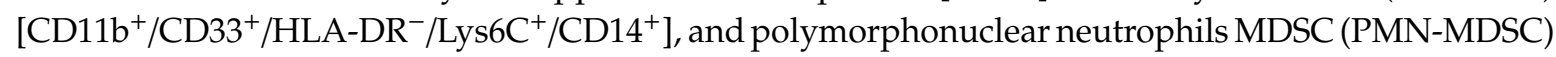

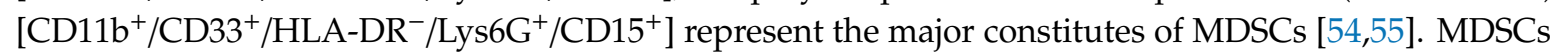
are induced in both inflammatory and cancerous conditions. Factors induced MDSC to include PGE2, IL-1 $\beta$, IL-6, VEGF, and C5a.complement component [56]. This could explain the relationship between chronic inflammation and progression to cancer. In a genetically engineered mouse model of penile SCC, huang et al. described changes in tumor microenvironment with a marked reduction in CD-8 ${ }^{+}$ $\mathrm{T}$ cells, NK cells, B cells, and tumor-associated macrophages, while there was a marked increase in $\mathrm{CD}-11 \mathrm{~b}{ }^{+}$with its ability to suppress the proliferation of the cytotoxic T cells [57].

Several studies have reported that tumor-infiltrating-MDSCs suppress the immune system by producing arginase, resulting in depletion of L-arginine in the tumor microenvironment and suppression of T-cell response $[58,59]$. Of note, the arginase enzyme has many isoforms; the cytosolic arginase- 1 and the mitochondrial arginase- 2 enzyme. Arginase expression by MDSC is induced by several factors, including immunosuppressive cytokines (TGF- $\beta$, IL-4, IL-10, and IL-13), tissue hypoxia, and acidosis [60]. Recently, there is increasing evidence linking the expression of arginase-1/2 with poor prognosis in several cancers, including head and neck cancer, pancreatic cancer, and acute 
myeloid leukemia [61-63]. However, expression of arginase in genitourinary cancers has not yet been described—particularly prostate cancer and renal cell carcinoma [64-66].

The presence of MDSCs in the TME contributes to tumor-mediated immune escape and bear a negative correlation to OS [53].

The expansion of MDSCs may be suppressed in many instances. In HNSCC, tadalafil, in its function as a phosphodiesterase-5 (PDE5) inhibitor, has demonstrated significant immunomodulation of the TME by lowering MDSCs and $\mathrm{T}_{\text {regs, }}$ while increasing tumor-infiltrating CD8 ${ }^{+} \mathrm{T}$ cells in a dose-dependent fashion [55,67]. In RCC and prostate cancer, sunitinib, as a VEGF, PDGFR, and receptor tyrosine kinase inhibitor, has demonstrated promise in the reduction of MDSCs [68,69]. Additionally, in a genetically engineered mouse (GEM) model of pSCC, the use of cabozantinib or celecoxib has exhibited a synergistic effect with immune checkpoints inhibitors (ICB) by lowering MDSCs positive for CD-11b ${ }^{+}$and $\mathrm{Ly}_{6} \mathrm{G}^{+}$[57].

Moreover, cabozantinib is a small molecular inhibitor of the Tyrosine kinases c-Met and VEGFR2 that has been shown to increase MDSC CD40 ${ }^{+}$expression compared to baseline in metastatic urothelial carcinoma ( $p=0.0005)$ [70]. CD40 activation of dendritic cells in the TME has, in turn, been linked to increased T cell-mediated immunity [71].

Currently, there are ongoing trials to test the efficacy of combination immunotherapies in advanced genitourinary cancers, including penile SCC. Examples include aphase $\frac{1}{2}$ clinical trial (NCT03866382) to investigate the efficacy of the combination of nivolumab and ipilimumab in addition to cabozantinib in rare genitourinary tumors [56]. Additionally, there is a phase 1 clinical trial (NCT02496208) investigating cabozantinib and nivolumab with or without ipilimumab in metastatic genitourinary tumors [69].

\section{HPV Role in Tumor Immune Microenvironment}

The relationship of HPV to the penile SCC TME represents an area of active interest for immunotherapy augmentation. Though there are variations in the prevalence of HPV that are primarily attributed to differences in sampling, viral molecular testing, and population studied, a systematic review of 1266 invasive penile SCC patients reported that in North America, up to $48.7 \%$ of penile SCC harbor HPV DNA. The vast majority of HPV-positive cases were represented by the high-risk HPV (hrHPV) 16 and 18 subtypes, $30.8 \%$ and $6.6 \%$, respectively [5]. Stratified by HPV status, hrHPV negativity in 213 penile SCC correlated significantly with poor disease-specific survival (HR 9.7, $p<0.01$ ) [23]. Viral positivity in penile SCC has repeatedly demonstrated favorable outcomes in survival, which may be linked to a theoretical increased production of neo-antigens [72]. However, the detection of HPV infection is not enough evidence of HPV-induced cancer. Therefore, there has been a growing interest in discovering new markers that can prove transcriptionally active infections [73]. Zargar-Shoshtari et al. investigated the potential clinical utility of two common tumor proteins, p16 and p53, in the HPV pathway [74]. The authors reported that patients with negative p16 and positive p53 are at increased risk of nodal metastases (OR: 4.4, 95\% CI: 1.04-18.6). Also, they reported that positive p16 status was associated with longer cancer-specific survival (HR: 0.36, 95\% CI: 0.13-0.99), with the worst CSS was seen in patients with lymph node-positive disease, as well as double negative of p16 and p53 [74]. Moreover, Aziz et al. investigated the prognostic value of the upregulation of PI3K-AKT-mTOR signaling pathway in penile SCC [75]. The authors reported that increased expression of PI3K-AKT-mTOR was associated with a lower risk of recurrence and overall mortality. They suggested that the use of mTOR pathway biomarkers with HPV infection status may demonstrate a prognostic value that can help in the risk stratification of patients with penile SCC [75].

In an IHC study, $\mathrm{HPV}^{+}$cases contained significantly higher stromal cytotoxic $\left(\mathrm{CD}^{+}\right) \mathrm{T}$ cells than $\mathrm{HPV}^{-}$cases $(p=0.04)$, representing a significant effect of HPV on the penile SCC TME [30]. Moreover, Lyford-Pike et al. reported that $70 \%$ of HPV-associated head and neck SCC demonstrated positive expression of the immunosuppressive molecule PD-L1 on both tumor cells and CD-68+ TAMs [76]. It has been reported that the majority of CD-8+ Tumor-infiltrating lymphocyte in HPV- associated 
head and neck SCC express PD-1, suggesting the benefits of using immune checkpoint blockades in these patients [76,77].

In light of the increasing relevance of HPV to penile SCC management, the European Association of Urology penile cancer 2018 update now recommends that the pathological evaluation of penile carcinoma specimens must include: (1) An assessment of the HPV status; (2) a diagnosis of the SCC subtype; and (3) an assessment of surgical margins including the width of the surgical margin [15].

There are several promising clinical trials investigating combinatorial immunotherapy augmented with HPV-targeted vaccines in HPV-associated malignancies. The phase $\frac{1}{2}$ trial NCT04432597 is testing an HPV vaccine in combination with an anti-PDL1/TGF-Beta Trap drug. The phase 2 trial NCT03439085 is testing an HPV vaccine with durvulumab, a human immunoglobulin G1 kappa monoclonal antibody targeting PD-L1. The phase 2 trial NCT03427411 is studying the efficacy of M7824, a bifunctional fusion protein targeting TGF- $\beta$ and PD-L1, for which phase 1 data has already demonstrated an encouraging safety profile and efficacy potential [78]. Another phase $\frac{1}{2}$ trial NCT04287868 is utilizing a combination of M7824 and vaccinations in patients with advanced HPV-associated malignancies [79].

\section{Tumor Mutational Burden}

Tumor Mutational Burden (TMB) was described as the number of nonsynonymous somatic mutations in the coding area of tumor cells per megabase (MB) of DNA. These somatic mutations influence the expression of tumor-specific epitopes (neoantigens) that are targetable by the host immune system [80]. TMB has been described in tumors with mismatch repair defect (MMR), or microsatellite instability (MSI) defect, such as colorectal cancers, or defect in DNA replication [81,82]. However, the prevalence of TMB varies widely across tumors, with non-small cell lung cancer (NSCLC) demonstrates the largest number of these mutations $(0.1-100 \mathrm{mut} / \mathrm{Mb})[83,84]$. The reported wide variance in the prevalence of TMB is also partly due to the lack of standardization of TMB quantification and reporting system.

TMB has been suggested as a potential biomarker of patients' prognosis. It has been hypothesized that increased expression of TMB indicates increased expression of PD-L1 and durable response to immune checkpoints inhibitors [85]. Recently, the Food and Drug Administration (FDA) has approved the use of pembrolizumab in patients with TMB $\geq 10$ mutation/megabase [86]. This was based on the data from the non-randomized, open-label KEYNOTE-158 trial. They reported an objective response rate of $29 \%$ (95CI: $21 \%-39 \%$ ), with approximately $50 \%$ of the responses were greater than two years [86,87].

Cancers with mismatch repair (MMR) deficiency, which invariably contributes to very high mutation rates, have consistently responded to pembrolizumab (PD-L1 blockade) [88]., Additionally, atezolizumab, an engineered humanized immunoglobulin G1 monoclonal antibody for PD-L1, has shown tolerability and durable activity in urothelial cancers with high TMB in proportion to increased levels of PD-L1 expression on immune cells [89]. Moreover, Van Allen et al. studied the relationship between response to CTLA-4 blockade and the genetic sequencings and mutations [90]. They reported that TMB and expression of cytotoxic cells in the tumor microenvironment were significant predictors of response to CTLA-4.

In addition to that, IFN-gamma related genes were also associated with durable response to immunotherapy. In a study of top genes associated with response to pembrolizumb in patients with metastatic melanoma, the preliminary IFN-gamma 10 gene signatures were significantly associated with good response and were able to predictor responders from non-responders to pembrolizumab [91]. These genes included IFNG, STAT1, CCR5, CXCL9, CXCL10, CXCL11, IDO1, PRF1, GZMA, and MHCII HLA-DRA [91].

However, some chromosomal mutations are associated with poor response to immunotherapy. Davoli et al. reported that tumor aneuploidy or somatic copy number alterations (SCNAs) was associated with poor response to immunotherapy [92]. In addition, Xiao et al. studied in metastatic melanoma patients the relationship between TP53 mutation and the response to anti-CTLA-4 therapy. 
The authors reported that increased TP53 expression is significantly associated with poor response, poor progression-free survival, and poor overall survival, suggesting it as a negative predictor for response to CTLA-4 blockade [93].

Specific somatic mutations, copy number alterations, and gene and miRNA expression patterns have been demonstrated to be significantly associated with shorter time to progression or decreased survival. A 2018 study of 25 penile SCC patients treated with $1^{\text {st }}$-line cisplatin-based chemotherapy studied the expression of 738 genes. In univariate analysis, upregulated MAML2 $(p=0.004)$, KITLG $(p \leq 0.0001)$, and JAK1 $(p=0.029)$ genes were associated with poor overall survival. In contrast, genes, such as upregulated FANCA, were associated with better overall survival $(p=0.024)$ [94].

Despite the significant correlation of specific genetic alterations and expression patterns to penile SCC prognosis, a study of 27 whole-exome sequenced penile SCC tumors, investigating 810 genes, could not demonstrate an association between overall mutational burden and tumor stage, grade, or age though this relationship remains to be further explored in relation to immunotherapy response [95].

Feber et al. studied the genetic alteration in penile squamous cell carcinoma patients. Interestingly, the authors reported that tumors with high HPV viral load have a lower tumor mutational load than HPV negative tumors. This, in combination with the identification of a strong CpG signature in HPV-negative tumors $(p<0.001)$, suggests that studies of changes to the epigenome rather in addition to direct genetic alteration, may unveil key targets in the development of penile SCC [95]. Of note, Genetic studies of penile SCC have demonstrated at least 30\% of cases exhibited a targetable gene alteration with many similarities with other SCCs, suggesting similar biology and potential targeting agent [96].

Additionally, recent reports have described the upregulation of Sox2 and Ptgs2 transcriptional factors in skin and penile SCC $[57,97]$. Sox 2 is a $\beta$-catenin transcriptional target, upregulated in cancer stem cells, and absent in normal epidermis, while Ptgs 2, or better known as Cox2, is a pro-inflammatory gene that induces prostaglandins production from arachidonic acid resulting in cytokine upregulation and inflammatory reactions. These genes act as the master regulators of cancer stem cells that play an important role of Sox-2 in tumor initiation and progression. Boumahdi et al. reported that conditional deletion of Sox2-gene results in tumor cell regression, consistent with their critical role for disease continuity [97].

\section{Conclusions}

Penile squamous cell carcinoma is a complex disease with a debilitating nature. However, the current revolution and advances in immunotherapies hold promises for cancer patients, including penile cancer. Despite the lack of level1 evidence for using immunotherapy in penile cancer, most penile squamous cell carcinoma expresses PD-L1, which provides a rationale for considering immunotherapy. There are ongoing trials studying the use of a combination of anti-PD- 1 and anti-CTLA-4 in rare Genitourinary cancers. Additionally, Preclinical data suggested synergistic efficacy with using combination therapy of Immune Checkpoints blockades (ICB) with MDSC-inhibiting agents, such as cabozantinib or celecoxib, particularly in the setting of chemoresistant disease. Moreover, the current advances in the understanding of tumor microenvironment and tumor mutational burden could help to select patients with a higher chance to respond and benefit from therapy. Given the rarity of the disease, there is an immense need for a multi-institutional collaboration alongside industrial support, as well as patient advocacy, to develop the second stage of treatment of penile cancer in the era of immunotherapy.

Author Contributions: Conceptualization, P.E.S., J.C., A.H., M.E.A., and S.F.; methodology, P.E.S., M.E.A., and S.F.; validation, A.H., M.E.A., and P.E.S.; investigation, M.E.A., A.H., and S.F.; resources, M.E.A., S.F., P.E.S., J.C., and A.H.; data curation, A.H.; writing—original draft preparation, M.E.A., A.H., and S.F.; writing-review and editing, P.E.S., J.C.; visualization, P.E.S. and J.C.; supervision, P.E.S. and J.C.; project administration, P.E.S.; All authors have read and agreed to the published version of the manuscript.

Funding: This research received no external funding. 
Conflicts of Interest: Philippe E Spiess serves as the vice-chair of the NCCN Bladder and Penile Cancer Panel and the President of the Global Society of Rare Genitourinary Tumors. All other authors declare no conflict of interest.

\section{References}

1. Siegel, R.L.; Miller, K.D.; Jemal, A. Cancer statistics, 2020. CA Cancer J. Clin. 2020, 70, 7-30. [CrossRef] [PubMed]

2. Flaherty, A.; Kim, T.; Giuliano, A.; Magliocco, A.; Hakky, T.S.; Pagliaro, L.C.; Spiess, P.E. Implications for human papillomavirus in penile cancer. Urol. Oncol. 2014, 32, 53.e1-53.e8. [CrossRef] [PubMed]

3. Bray, F.; Ferlay, J.; Soerjomataram, I.; Siegel, R.L.; Torre, L.A.; Jemal, A. Global cancer statistics 2018: GLOBOCAN estimates of incidence and mortality worldwide for 36 cancers in 185 countries. CA Cancer J. Clin. 2018, 68, 394-424. [CrossRef] [PubMed]

4. Burgers, J.K.; Badalament, R.A.; Drago, J.R. Penile cancer. Clinical presentation, diagnosis, and staging. Urol. Clin. N. Am. 1992, 19, 247-256. [PubMed]

5. Backes, D.; Kurman, R.; Pimenta, J.; Smith, J. Systematic review of human papillomavirus prevalence in invasive penile cancer. Cancer Causes Control CCC 2009, 20, 449-457. [CrossRef]

6. Daling, J.R.; Madeleine, M.M.; Johnson, L.G.; Schwartz, S.M.; Shera, K.A.; Wurscher, M.A.; Carter, J.J.; Porter, P.L.; Galloway, D.A.; McDougall, J.K.; et al. Penile cancer: Importance of circumcision, human papillomavirus and smoking in in situ and invasive disease. Int. J. Cancer 2005, 116, 606-616. [CrossRef]

7. Diorio, G.J.; Giuliano, A.R. The role of human papilloma virus in penile carcinogenesis and preneoplastic lesions: A potential target for vaccination and treatment strategies. Urol. Clin. N. Am. 2016, 43, 419-425. [CrossRef]

8. Larke, N.L.; Thomas, S.L.; Dos Santos Silva, I.; Weiss, H.A. Male circumcision and penile cancer: A systematic review and meta-analysis. Cancer Causes Control CCC 2011, 22, 1097-1110. [CrossRef]

9. Ulff-Møller, C.J.; Simonsen, J.; Frisch, M. Marriage, cohabitation and incidence trends of invasive penile squamous cell carcinoma in Denmark 1978-2010. Int. J. Cancer 2013, 133, 1173-1179. [CrossRef]

10. Dotto, G.P.; Rustgi, A.K. Squamous cell cancers: A unified perspective on biology and genetics. Cancer Cell 2016, 29, 622-637. [CrossRef]

11. Di Lorenzo, G.; Perdonà, S.; Buonerba, C.; Sonpavde, G.; Gigantino, V.; Pannone, G.; Quarto, G.; Ferro, M.; Gaudioso, G.; Terracciano, D.; et al. Cytosolic phosphorylated EGFR is predictive of recurrence in early stage penile cancer patients: A retropective study. J. Trans. Med. 2013, 11, 161. [CrossRef] [PubMed]

12. Verhoeven, R.H.; Janssen-Heijnen, M.L.; Saum, K.U.; Zanetti, R.; Caldarella, A.; Holleczek, B.; Brewster, D.H.; Hakulinen, T.; Horenblas, S.; Brenner, H.; et al. Population-based survival of penile cancer patients in Europe and the United States of America: No improvement since 1990. Eur. J. Cancer 2013, 49, 1414-1421. [CrossRef] [PubMed]

13. Clark, P.E.; Spiess, P.E.; Agarwal, N.; Biagioli, M.C.; Eisenberger, M.A.; Greenberg, R.E.; Herr, H.W.; Inman, B.A.; Kuban, D.A.; Kuzel, T.M.; et al. Penile cancer: Clinical practice guidelines in oncology. J. Natl. Compr. Canc. Netw. 2013, 11, 594-615. [CrossRef] [PubMed]

14. Slaton, J.W.; Morgenstern, N.; Levy, D.A.; Santos, M.W., Jr.; Tamboli, P.; Ro, J.Y.; Ayala, A.G.; Pettaway, C.A. Tumor stage, vascular invasion and the percentage of poorly differentiated cancer: Independent prognosticators for inguinal lymph node metastasis in penile squamous cancer. J. Urol. 2001, 165, 1138-1142. [CrossRef]

15. Hakenberg, O.W.; Compérat, E.; Minhas, S.; Necchi, A.; Protzel, C.; Watkin, N. EAU Guidelines on Penile Cancer. Available online: https://uroweb.org/wp-content/uploads/EAU-Guidelines-Penile-Cancer-2018.pdf (accessed on 30 September 2020).

16. Pagliaro, L.C.; Williams, D.L.; Daliani, D.; Williams, M.B.; Osai, W.; Kincaid, M.; Wen, S.; Thall, P.F.; Pettaway, C.A. Neoadjuvant paclitaxel, ifosfamide, and cisplatin chemotherapy for metastatic penile cancer: A phase II study. J. Clin. Oncol. 2010, 28, 3851-3857. [CrossRef]

17. Azizi, M.; Aydin, A.M.; Hajiran, A.; Lai, A.; Kumar, A.; Peyton, C.C.; Minhas, S.; Sonpavde, G.P.; Chahoud, J.; Pagliaro, L.C.; et al. Systematic review and meta-analysis-Is there a benefit in using neoadjuvant systemic chemotherapy for locally advanced penile squamous cell carcinoma? J. Urol. 2020, 203, 1147-1155. [CrossRef] [PubMed] 
18. Djajadiningrat, R.S.; Bergman, A.M.; Van Werkhoven, E.; Vegt, E.; Horenblas, S. Neoadjuvant taxane-based combination chemotherapy in patients with advanced penile cancer. Clin. Genitourin. Cancer 2015, 13, 44-49. [CrossRef]

19. Wang, J.; Pettaway, C.A.; Pagliaro, L.C. Treatment for metastatic penile cancer after first-line chemotherapy failure: Analysis of response and survival outcomes. Urology 2015, 85, 1104-1110. [CrossRef]

20. Cohen, E.E.W.; Soulières, D.; Le Tourneau, C.; Dinis, J.; Licitra, L.; Ahn, M.J.; Soria, A.; Machiels, J.P.; Mach, N.; Mehra, R.; et al. Pembrolizumab versus methotrexate, docetaxel, or cetuximab for recurrent or metastatic head-and-neck squamous cell carcinoma (KEYNOTE-040): A randomised, open-label, phase 3 study. Lancet 2019, 393, 156-167. [CrossRef]

21. Gooden, M.J.M.; De Bock, G.H.; Leffers, N.; Daemen, T.; Nijman, H.W. The prognostic influence of tumour-infiltrating lymphocytes in cancer: A systematic review with meta-analysis. Br. J. Cancer 2011, 105, 93-103. [CrossRef]

22. Echarti, A.; Hecht, M.; Büttner-Herold, M.; Haderlein, M.; Hartmann, A.; Fietkau, R.; Distel, L. CD8+ and regulatory $\mathrm{T}$ cells differentiate tumor immune phenotypes and predict survival in locally advanced head and neck cancer. Cancers 2019, 11, 1398. [CrossRef]

23. Ottenhof, S.R.; Djajadiningrat, R.S.; Thygesen, H.H.; Jakobs, P.J.; Jóźwiak, K.; Heeren, A.M.; De Jong, J.; Sanders, J.; Horenblas, S.; Jordanova, E.S. The prognostic value of immune factors in the tumor microenvironment of penile squamous cell carcinoma. Front. Immunol. 2018, 9. [CrossRef] [PubMed]

24. Chen, D.S.; Mellman, I. Elements of cancer immunity and the cancer-immune set point. Nature 2017, 541, 321-330. [CrossRef]

25. de Vries, H.M.; Ottenhof, S.R.; Horenblas, S.; van der Heijden, M.S.; Jordanova, E.S. Defining the tumor microenvironment of penile cancer by means of the cancer immunogram. Eur. Urol. Focus 2019, 5, 718-721. [CrossRef] [PubMed]

26. Ino, Y.; Yamazaki-Itoh, R.; Shimada, K.; Iwasaki, M.; Kosuge, T.; Kanai, Y.; Hiraoka, N. Immune cell infiltration as an indicator of the immune microenvironment of pancreatic cancer. Br. J. Cancer 2013, 108, 914-923. [CrossRef] [PubMed]

27. Necchi, A.; Joseph, R.W.; Loriot, Y.; Hoffman-Censits, J.; Perez-Gracia, J.L.; Petrylak, D.P.; Derleth, C.L.; Tayama, D.; Zhu, Q.; Ding, B.; et al. Atezolizumab in platinum-treated locally advanced or metastatic urothelial carcinoma: Post-progression outcomes from the phase II IMvigor210 study. Ann. Oncol. 2017, 28, 3044-3050. [CrossRef] [PubMed]

28. Yu, P.; Fu, Y.-X. Tumor-infiltrating T lymphocytes: Friends or foes? Lab. Invest. 2006, 86, 231-245. [CrossRef]

29. Jiang, Y.; Li, Y.; Zhu, B. T-cell exhaustion in the tumor microenvironment. Cell Death Dis. 2015, 6, e1792. [CrossRef]

30. Chahoud, J.; Netto, F.; Segura, R.L.; Cuentas, E.R.P.; Lu, X.; Rao, P.; Wistuba, I.I.; Pickering, C.R.; Pettaway, C.A. Tumor immune microenvironment alterations in penile squamous cell carcinoma using multiplex immunofluorescence and image analysis approaches. J. Clin. Oncol. 2020, 38, 4. [CrossRef]

31. Vassallo, J.; Rodrigues, A.F.; Campos, A.H.; Rocha, R.M.; da Cunha, I.W.; Zequi, S.C.; Guimarães, G.C.; da Fonseca, F.P.; Lopes, A.; Cubilla, A.; et al. Pathologic and imunohistochemical characterization of tumoral inflammatory cell infiltrate in invasive penile squamous cell carcinomas: Fox-P3 expression is an independent predictor of recurrence. Tumour Biol. 2015, 36, 2509-2516. [CrossRef]

32. Udager, A.M.; Liu, T.Y.; Skala, S.L.; Magers, M.J.; McDaniel, A.S.; Spratt, D.E.; Feng, F.Y.; Siddiqui, J.; Cao, X.; Fields, K.L.; et al. Frequent PD-L1 expression in primary and metastatic penile squamous cell carcinoma: Potential opportunities for immunotherapeutic approaches. Ann. Oncol. 2016, 27, 1706-1712. [CrossRef]

33. Ottenhof, S.R.; Djajadiningrat, R.S.; De Jong, J.; Thygesen, H.H.; Horenblas, S.; Jordanova, E.S. Expression of Programmed Death Ligand 1 (PD-L1) in penile cancer is of prognostic value and associated with HPV status. J. Urol. 2017, 193, 690-697. [CrossRef] [PubMed]

34. Trafalis, D.T.; Alifieris, C.E.; Kalantzis, A.; Verigos, K.E.; Vergadis, C.; Sauvage, S. Evidence for efficacy of treatment with the anti-PD-1 Mab nivolumab in radiation and multichemorefractory advanced penile squamous cell carcinoma. J. Immunother. 2018, 41, 300-305. [CrossRef] [PubMed]

35. Valastyan, S.; Weinberg, R.A. Tumor metastasis: Molecular insights and evolving paradigms. Cell 2011, 147, 275-292. [CrossRef]

36. Nivolumab Combined with Ipilimumab for Patients with Advanced Rare Genitourinary Tumors. Available online: https://clinicaltrials.gov/ct2/show/NCT03333616 (accessed on 30 September 2020). 
37. Atezolizumab and Bevacizumab in Treating Patients with Rare Solid Tumors. Available online: https: //clinicaltrials.gov/ct2/show/NCT03074513 (accessed on 30 September 2020).

38. Pembrolizumab in Treating Patients with Rare Tumors That Cannot Be Removed by Surgery or Are Metastatic. Available online: https://clinicaltrials.gov/ct2/show/NCT02721732 (accessed on 30 September 2020).

39. De Paula, A.A.P.; Motta, E.D.; Alencar, R.D.C.; Saddi, V.A.; Da Silva, R.C.; Caixeta, G.N.; Almeida Netto, J.C.; Carneiro, M.A.D.S. The Impact of cyclooxygenase-2 and vascular endothelial growth factor C immunoexpression on the prognosis of penile carcinoma. J. Urol. 2012, 187, 134-140. [CrossRef] [PubMed]

40. Zahreddine, H.; Borden, K.L.B. Mechanisms and insights into drug resistance in cancer. Front. Pharmacol. 2013, 4. [CrossRef] [PubMed]

41. Heusinkveld, M.; De Vos Van Steenwijk, P.J.; Goedemans, R.; Ramwadhdoebe, T.H.; Gorter, A.; Welters, M.J.P.; Van Hall, T.; Van Der Burg, S.H. M2 macrophages induced by prostaglandin E2 and IL-6 from cervical carcinoma are switched to activated M1 macrophages by CD4+Th1 cells. J. Immunol. 2011, 187, 1157-1165. [CrossRef]

42. Hu, H.; Hang, J.J.; Han, T.; Zhuo, M.; Jiao, F.; Wang, L.W. The M2 phenotype of tumor-associated macrophages in the stroma confers a poor prognosis in pancreatic cancer. Tumour Biol. 2016, 37, 8657-8664. [CrossRef]

43. Heeren, A.M.; Punt, S.; Bleeker, M.C.; Gaarenstroom, K.N.; Van Der Velden, J.; Kenter, G.G.; De Gruijl, T.D.; Jordanova, E.S. Prognostic effect of different PD-L1 expression patterns in squamous cell carcinoma and adenocarcinoma of the cervix. Mod. Pathol. 2016, 29, 753-763. [CrossRef]

44. Karim, R.; Jordanova, E.S.; Piersma, S.J.; Kenter, G.G.; Chen, L.; Boer, J.M.; Melief, C.J.M.; Van Der Burg, S.H. Tumor-expressed B7-H1 and B7-DC in relation to PD-1+ T-Cell infiltration and survival of patients with cervical carcinoma. Clin. Cancer Res. 2009, 15, 6341-6347. [CrossRef]

45. Smola, S. Immunopathogenesis of HPV-associated cancers and prospects for immunotherapy. Viruses 2017, 9. [CrossRef] [PubMed]

46. Johnson, D.E.; O'Keefe, R.A.; Grandis, J.R. Targeting the IL-6/JAK/STAT3 signalling axis in cancer. Nat. Rev. Clin. Oncol. 2018, 15, 234-248. [CrossRef] [PubMed]

47. Kitamura, H.; Ohno, Y.; Toyoshima, Y.; Ohtake, J.; Homma, S.; Kawamura, H.; Takahashi, N.; Taketomi, A. Interleukin-6/STAT3 signaling as a promising target to improve the efficacy of cancer immunotherapy. Cancer Sci. 2017, 108, 1947-1952. [CrossRef] [PubMed]

48. Heo, T.H.; Wahler, J.; Suh, N. Potential therapeutic implications of IL-6/IL-6R/gp130-targeting agents in breast cancer. Oncotarget 2016, 7, 15460-15473. [CrossRef]

49. Fizazi, K.; De Bono, J.S.; Flechon, A.; Heidenreich, A.; Voog, E.; Davis, N.B.; Qi, M.; Bandekar, R.; Vermeulen, J.T.; Cornfeld, M.; et al. Randomised phase II study of siltuximab (CNTO 328), an anti-IL-6 monoclonal antibody, in combination with mitoxantrone/prednisone versus mitoxantrone/prednisone alone in metastatic castration-resistant prostate cancer. Eur. J. Cancer 2012, 48, 85-93. [CrossRef]

50. Angevin, E.; Tabernero, J.; Elez, E.; Cohen, S.J.; Bahleda, R.; van Laethem, J.L.; Ottensmeier, C.; Lopez-Martin, J.A.; Clive, S.; Joly, F.; et al. A phase I/II, multiple-dose, dose-escalation study of siltuximab, an anti-interleukin-6 monoclonal antibody, in patients with advanced solid tumors. Clin. Cancer Res. 2014, 20, 2192-2204. [CrossRef] [PubMed]

51. Gabrilovich, D.I.; Nagaraj, S. Myeloid-derived suppressor cells as regulators of the immune system. Nat. Rev. Immunol. 2009, 9, 162-174. [CrossRef]

52. Elliott, L.A.; Doherty, G.A.; Sheahan, K.; Ryan, E.J. Human tumor-infiltrating myeloid cells: Phenotypic and functional diversity. Front. Immunol. 2017, 8. [CrossRef]

53. Draghiciu, O.; Lubbers, J.; Nijman, H.W.; Daemen, T. Myeloid derived suppressor cells-An overview of combat strategies to increase immunotherapy efficacy. OncoImmunology 2015, 4, e954829. [CrossRef]

54. Gabrilovich, D.I.; Ostrand-Rosenberg, S.; Bronte, V. Coordinated regulation of myeloid cells by tumours. Nat. Rev. Immunol. 2012, 12, 253-268. [CrossRef]

55. Weed, D.T.; Vella, J.L.; Reis, I.M.; De La Fuente, A.C.; Gomez, C.; Sargi, Z.; Nazarian, R.; Califano, J.; Borrello, I.; Serafini, P. Tadalafil reduces myeloid-derived suppressor cells and regulatory $\mathrm{T}$ cells and promotes tumor immunity in patients with head and neck squamous cell carcinoma. Clin. Cancer Res. 2015, 21, 39-48. [CrossRef]

56. Ostrand-Rosenberg, S.; Sinha, P. Myeloid-derived suppressor cells: Linking inflammation and cancer. J. Immunol. 2009, 182, 4499-4506. [CrossRef] [PubMed] 
57. Huang, T.; Cheng, X.; Chahoud, J.; Sarhan, A.; Tamboli, P.; Rao, P.; Guo, M.; Manyam, G.; Zhang, L.; Xiang, Y.; et al. Effective combinatorial immunotherapy for penile squamous cell carcinoma. Nat. Commun. 2020, 11, 2124. [CrossRef] [PubMed]

58. Rodriguez, P.C.; Quiceno, D.G.; Zabaleta, J.; Ortiz, B.; Zea, A.H.; Piazuelo, M.B.; Delgado, A.; Correa, P.; Brayer, J.; Sotomayor, E.M.; et al. Arginase I production in the tumor microenvironment by mature myeloid cells inhibits T-cell receptor expression and antigen-specific T-cell responses. Cancer Res. 2004, 64, 5839-5849. [CrossRef]

59. Zea, A.H.; Rodriguez, P.C.; Atkins, M.B.; Hernandez, C.; Signoretti, S.; Zabaleta, J.; McDermott, D.; Quiceno, D.; Youmans, A.; O'Neill, A.; et al. Arginase-producing myeloid suppressor cells in renal cell carcinoma patients: A mechanism of tumor evasion. Cancer Res. 2005, 65, 3044-3048. [CrossRef]

60. Grzywa, T.M.; Sosnowska, A.; Matryba, P.; Rydzynska, Z.; Jasinski, M.; Nowis, D.; Golab, J. Myeloid cell-derived arginase in cancer immune response. Front. Immunol. 2020, 11, 938. [CrossRef] [PubMed]

61. Bron, L.; Jandus, C.; Andrejevic-Blant, S.; Speiser, D.E.; Monnier, P.; Romero, P.; Rivals, J.P. Prognostic value of arginase-II expression and regulatory T-cell infiltration in head and neck squamous cell carcinoma. Int. J. Cancer 2013, 132, E85-93. [CrossRef]

62. Ino, Y.; Yamazaki-Itoh, R.; Oguro, S.; Shimada, K.; Kosuge, T.; Zavada, J.; Kanai, Y.; Hiraoka, N. Arginase II expressed in cancer-associated fibroblasts indicates tissue hypoxia and predicts poor outcome in patients with pancreatic cancer. PLoS ONE 2013, 8, e55146. [CrossRef]

63. Mussai, F.; De Santo, C.; Abu-Dayyeh, I.; Booth, S.; Quek, L.; McEwen-Smith, R.M.; Qureshi, A.; Dazzi, F.; Vyas, P.; Cerundolo, V. Acute myeloid leukemia creates an arginase-dependent immunosuppressive microenvironment. Blood 2013, 122, 749-758. [CrossRef]

64. Mumenthaler, S.M.; Yu, H.; Tze, S.; Cederbaum, S.D.; Pegg, A.E.; Seligson, D.B.; Grody, W.W. Expression of arginase II in prostate cancer. Int. J. Oncol. 2008, 32, 357-365. [CrossRef]

65. Yoon, C.Y.; Shim, Y.J.; Kim, E.H.; Lee, J.H.; Won, N.H.; Kim, J.H.; Park, I.S.; Yoon, D.K.; Min, B.H. Renal cell carcinoma does not express argininosuccinate synthetase and is highly sensitive to arginine deprivation via arginine deiminase. Int. J. Cancer 2007, 120, 897-905. [CrossRef]

66. Ochocki, J.D.; Khare, S.; Hess, M.; Ackerman, D.; Qiu, B.; Daisak, J.I.; Worth, A.J.; Lin, N.; Lee, P.; Xie, H.; et al. Arginase 2 suppresses renal carcinoma progression via biosynthetic cofactor pyridoxal phosphate depletion and increased polyamine toxicity. Cell Metab. 2018, 27, 1263-1280.e6. [CrossRef] [PubMed]

67. Serafini, P.; Meckel, K.; Kelso, M.; Noonan, K.; Califano, J.; Koch, W.; Dolcetti, L.; Bronte, V.; Borrello, I. Phosphodiesterase- 5 inhibition augments endogenous antitumor immunity by reducing myeloid-derived suppressor cell function. J. Exp. Med. 2006, 203, 2691-2702. [CrossRef]

68. Motzer, R.J.; Hutson, T.E.; Tomczak, P.; Michaelson, M.D.; Bukowski, R.M.; Rixe, O.; Oudard, S.; Negrier, S.; Szczylik, C.; Kim, S.T.; et al. Sunitinib versus interferon alfa in metastatic renal-cell carcinoma. N. Engl. J. Med. 2007, 356, 115-124. [CrossRef] [PubMed]

69. Dror Michaelson, M.; Regan, M.M.; Oh, W.K.; Kaufman, D.S.; Olivier, K.; Michaelson, S.Z.; Spicer, B.; Gurski, C.; Kantoff, P.W.; Smith, M.R. Phase II study of sunitinib in men with advanced prostate cancer. Ann. Oncol. 2009, 20, 913-920. [CrossRef] [PubMed]

70. Apolo, A.B.; Tomita, Y.; Lee, M.-J.; Lee, S.; Frosch, A.; Steinberg, S.M.; Gulley, J.L.; Schlom, J.; Bottaro, D.P.; Trepel, J.B. Effect of cabozantinib on immunosuppressive subsets in metastatic urothelial carcinoma. J. Clin. Oncol. 2014, 32, 4501. [CrossRef]

71. Vonderheide, R.H. The Immune revolution: A case for priming, not checkpoint. Cancer Cell 2018, 33, 563-569. [CrossRef]

72. Lont, A.P.; Kroon, B.K.; Horenblas, S.; Gallee, M.P.W.; Berkhof, J.; Meijer, C.J.L.M.; Snijders, P.J.F. Presence of high-risk human papillomavirus DNA in penile carcinoma predicts favorable outcome in survival. Int. J. Cancer 2006, 119, 1078-1081. [CrossRef]

73. Mannweiler, S.; Sygulla, S.; Winter, E.; Regauer, S. Two major pathways of penile carcinogenesis: HPV-induced penile cancers overexpress $\mathrm{p} 16^{\text {ink4a }}, \mathrm{HPV}$-negative cancers associated with dermatoses express p53, but lack p16 ink4a overexpression. J. Am. Acad. of Dermatol. 2013, 69, 73-81. [CrossRef]

74. Zargar-Shoshtari, K.; Spiess, P.E.; Berglund, A.E.; Sharma, P.; Powsang, J.M.; Giuliano, A.; Magliocco, A.M.; Dhillon, J. clinical significance of p53 and p16(ink4a) status in a contemporary North American penile carcinoma cohort. Clin. Genitourin. Cancer 2016, 14, 346-351. [CrossRef] 
75. Azizi, M.; Tang, D.H.; Verduzco, D.; Peyton, C.C.; Chipollini, J.; Yuan, Z.; Schaible, B.J.; Zhou, J.M.; Johnstone, P.A.; Giuliano, A.; et al. Impact of PI3K-AKT-mTOR signaling pathway up-regulation on prognosis of penile squamous-cell carcinoma: Results from a tissue microarray study and review of the literature. Clin. Genitourin. Cancer 2019, 17, e80-e91. [CrossRef] [PubMed]

76. Lyford-Pike, S.; Peng, S.; Young, G.D.; Taube, J.M.; Westra, W.H.; Akpeng, B.; Bruno, T.C.; Richmon, J.D.; Wang, H.; Bishop, J.A.; et al. Evidence for a role of the PD-1:PD-L1 pathway in immune resistance of HPV-associated head and neck squamous cell carcinoma. Cancer Res. 2013, 73, 1733-1741. [CrossRef] [PubMed]

77. Badoual, C.; Hans, S.; Merillon, N.; Van Ryswick, C.; Ravel, P.; Benhamouda, N.; Levionnois, E.; Nizard, M.; Si-Mohamed, A.; Besnier, N. PD-1-expressing tumor-infiltrating T cells are a favorable prognostic biomarker in HPV-associated head and neck cancer. Cancer Res. 2013, 73, 128-138. [CrossRef]

78. Strauss, J.; Gatti-Mays, M.E.; Cho, B.; Salas, S.; McClay, E.; Redman, J.; Sater, H.A.; Donahue, R.N.; Lamping, E.; Burmeister, A.; et al. Abstract CT075: Phase I evaluation of M7824, a bifunctional fusion protein targeting TGF- $\beta$ and PD-L1, in patients with human papillomavirus (HPV)-associated malignancies. Cancer Res. 2019, 79, CT075. [CrossRef]

79. Rizvi, N.A.; Hellmann, M.D.; Snyder, A.; Kvistborg, P.; Makarov, V.; Havel, J.J.; Lee, W.; Yuan, J.; Wong, P.; Ho, T.S.; et al. Cancer immunology. Mutational landscape determines sensitivity to PD-1 blockade in non-small cell lung cancer. Science 2015, 348, 124-128. [CrossRef]

80. Goto, Y. Tumor Mutation burden: Is it ready for the clinic? J. Clin. Oncol. 2018, 36, 2978-2979. [CrossRef]

81. Quiroga, D.; Lyerly, H.K.; Morse, M.A. Deficient mismatch repair and the role of immunotherapy in metastatic colorectal cancer. Curr. Treat Options Oncol. 2016, 17, 41. [CrossRef] [PubMed]

82. Chalmers, Z.R.; Connelly, C.F.; Fabrizio, D.; Gay, L.; Ali, S.M.; Ennis, R.; Schrock, A.; Campbell, B.; Shlien, A.; Chmielecki, J.; et al. Analysis of 100,000 human cancer genomes reveals the landscape of tumor mutational burden. Genome Med. 2017, 9, 34. [CrossRef]

83. Alexandrov, L.B.; Nik-Zainal, S.; Wedge, D.C.; Aparicio, S.A.; Behjati, S.; Biankin, A.V.; Bignell, G.R.; Bolli, N.; Borg, A.; Børresen-Dale, A.L.; et al. Signatures of mutational processes in human cancer. Nature 2013, 500, 415-421. [CrossRef] [PubMed]

84. Lawrence, M.S.; Stojanov, P.; Polak, P.; Kryukov, G.V.; Cibulskis, K.; Sivachenko, A.; Carter, S.L.; Stewart, C.; Mermel, C.H.; Roberts, S.A.; et al. Mutational heterogeneity in cancer and the search for new cancer-associated genes. Nature 2013, 499, 214-218. [CrossRef]

85. Klempner, S.J.; Fabrizio, D.; Bane, S.; Reinhart, M.; Peoples, T.; Ali, S.M.; Sokol, E.S.; Frampton, G.; Schrock, A.B.; Anhorn, R.; et al. Tumor mutational burden as a predictive biomarker for response to immune checkpoint inhibitors: A review of current evidence. Oncologist 2020, 25, e147-e159. [CrossRef]

86. Subbiah, V.; Solit, D.B.; Chan, T.A.; Kurzrock, R. The FDA approval of pembrolizumab for adult and pediatric patients with tumor mutational burden $(\mathrm{TMB}) \geq 10$ : A decision centered on empowering patients and their physicians. Ann. Oncol. 2020, 31, 1115-1118. [CrossRef]

87. A Clinical Trial of Pembrolizumab (MK-3475) Evaluating Predictive Biomarkers in Subjects with Advanced Solid Tumors (KEYNOTE 158). Available online: https://clinicaltrials.gov/ct2/show/NCT02628067 (accessed on 30 September 2020).

88. Le, D.T.; Uram, J.N.; Wang, H.; Bartlett, B.R.; Kemberling, H.; Eyring, A.D.; Skora, A.D.; Luber, B.S.; Azad, N.S.; Laheru, D.; et al. PD1 blockade in tumors with mismatch-repair deficiency. N. Engl. J. Med. 2015, 372, 2509-2520. [CrossRef] [PubMed]

89. Rosenberg, J.E.; Hoffman-Censits, J.; Powles, T.; Van Der Heijden, M.S.; Balar, A.V.; Necchi, A.; Dawson, N.; O'Donnell, P.H.; Balmanoukian, A.; Loriot, Y.; et al. Atezolizumab in patients with locally advanced and metastatic urothelial carcinoma who have progressed following treatment with platinum-based chemotherapy: A single-arm, multicentre, phase 2 trial. Lancet 2016, 387, 1909-1920. [CrossRef]

90. Van Allen, E.M.; Miao, D.; Schilling, B.; Shukla, S.A.; Blank, C.; Zimmer, L.; Sucker, A.; Hillen, U.; Foppen, M.H.G.; Goldinger, S.M.; et al. Genomic correlates of response to CTLA-4 blockade in metastatic melanoma. Science 2015, 350, 207-211. [CrossRef]

91. Ayers, M.; Lunceford, J.; Nebozhyn, M.; Murphy, E.; Loboda, A.; Kaufman, D.R.; Albright, A.; Cheng, J.D.; Kang, S.P.; Shankaran, V.; et al. IFN- $\gamma$-related mRNA profile predicts clinical response to PD-1 blockade. J. Clin. Investig. 2017, 127, 2930-2940. [CrossRef] 
92. Davoli, T.; Uno, H.; Wooten, E.C.; Elledge, S.J. Tumor aneuploidy correlates with markers of immune evasion and with reduced response to immunotherapy. Science 2017, 355. [CrossRef]

93. Xiao, W.; Du, N.; Huang, T.; Guo, J.; Mo, X.; Yuan, T.; Chen, Y.; Ye, T.; Xu, C.; Wang, W.; et al. TP53 mutation as potential negative predictor for response of anti-CTLA-4 therapy in metastatic melanoma. EBioMedicine 2018, 32, 119-124. [CrossRef] [PubMed]

94. Necchi, A.; Eigl, B.J.; Yang, E.S.-H.; Bae, S.; Chandrashekar, D.; Chen, D.; Naik, G.; Mehta, A.; Giannatempo, P.; Colecchia, M.; et al. Gene expression profiling of advanced penile squamous cell carcinoma receiving cisplatin-based chemotherapy improves prognostication and identifies potential therapeutic targets. Eur. Urol. Focus 2018, 4, 733-736. [CrossRef]

95. Feber, A.; Arya, M.; de Winter, P.; Saqib, M.; Nigam, R.; Malone, P.R.; Tan, W.S.; Rodney, S.; Lechner, M.; Freeman, A.; et al. Epigenetics markers of metastasis and HPV-induced tumorigenesis in penile cancer. Clin. Cancer Res. 2015, 21, 1196-1206. [CrossRef]

96. Chahoud, J.; Pickering, C.R.; Pettaway, C.A. Genetics and penile cancer: Recent developments and implications. Curr. Opin. Urol. 2019, 29, 364-370. [CrossRef] [PubMed]

97. Boumahdi, S.; Driessens, G.; Lapouge, G.; Rorive, S.; Nassar, D.; Le Mercier, M.; Delatte, B.; Caauwe, A.; Lenglez, S.; Nkusi, E.; et al. SOX2 controls tumour initiation and cancer stem-cell functions in squamous-cell carcinoma. Nature 2014, 511, 246-250. [CrossRef] [PubMed]

Publisher's Note: MDPI stays neutral with regard to jurisdictional claims in published maps and institutional affiliations. 